\title{
Virtual Maintenance, Reality, and Systems: A Review
}

\author{
Kouroush Jenab ${ }^{1}$, Saeid Moslehpour ${ }^{2}$, Sam Khoury ${ }^{3}$ \\ ${ }^{1}$ Faculty of College of Business, Athens State University, Athens, AL, USA \\ ${ }^{2}$ Faculty of College of Engineering, Hartford University, West Hartford, CT, USA \\ ${ }^{3}$ Faculty of the Division of Business, Spring Hill College, AL, USA
}

\section{Article Info \\ Article history: \\ Received Jun 7, 2016 \\ Revised Sep 20, 2016 \\ Accepted Sep 3, 2016}

\section{Keyword:}

Virtual maintenance, reality, and systems

Virtual reality

Virtual training

\section{Corresponding Author:}

Kouroush Jenab,

Faculty of College of Business,

Athens State University,

Athens, AL, USA.

E-mail: jenab@ieee.org

\begin{abstract}
Virtual Reality is a computer-generated, mock environment that can allow people to interact with it in a seemingly real way by using certain types of specialized equipment. It is mainly used for training or educational purposes and allows for "real-life" training in a safe and monitored environment. Virtual training can be used in many different fields such as medical, military, biomedical research, aviation, and many others. However, this paper reviews the most cited publications related to the application of virtual reality for training in the United States Military. As a result, researchers can find research venues based on the challenges, risk, and infrastructures.
\end{abstract}

Copyright () 2016 Institute of Advanced Engineering and Science. All rights reserved.

\section{INTRODUCTION}

Virtual Maintenance is the world of virtual reality that allows an individual to be trained for a certain task. These tasks could include training, repair, and service to help maintain certain equipment. The fields of training that Virtual Maintenance intersects include aviation, combat, industrial, medical, gaming, and a wide range of other opportunities. Companies often embrace this kind of training because it can save the company money and can also help prepare their employees for a job in a safe environment. In this paper, the fields of Virtual Maintenance that will be covered include aviation (including military training), military (combat and training), and civil (medical and gaming).

Virtual reality and maintenance can be found in many of our fields. In aviation it has multiple uses, from training of pilots all the way to the maintenance personnel who take care and build the aircraft. For example, simulators prepare pilots to learn how to fly and execute emergency procedures without even stepping foot inside an actual aircraft. At the same time, maintenance personnel can study and learn how systems function and how to perform maintenance task to reduce the risk of damage to parts and the aircraft. The United States military uses virtual reality and simulation to prepare soldiers for combat and to reduce the use of resources like ammunition and fuel. In the civilian world, virtual reality brings many uses to the market. Doctors and nurses can train on computers as opposed to training on cadavers and live subjects. Furthermore, they can train on the delivery of babies and on diagnose of common diseases and ailments that patients may have. Virtual reality in physics and engineering opens a whole new world to development of industry. 


\section{CLASSIFICATION OF LITERATURE}

The documents and sources of information pertaining to virtual maintenance listed in Table 1 are based on the categories split up for review. Table 1 is broken down into three categories, which are Civil Uses, Military Uses, and Aviation Uses.

Table 1. Classification of Literature According to Topics of Virtual Maintenance

\begin{tabular}{lll}
\hline Number & Topic & References \\
\hline 1. & Civil Uses & $1,4,5,6,8,11,14,21,22,23,26,27,28$, \\
& & $29,30,31,32,33,35,36,42,43,46,47$, \\
& $49,50,51,52,53,54,55,56,72,74,75$, \\
2. & $76,77,86,87,92,93,102,107$ \\
& Military Uses & $3,7,9,13,16,17,20,24,31,34,37,38$, \\
& & $39,40,45,48,57,58,59,60,61,73,81$, \\
3. & $82,83,84,88,89,90,95,101,103,104$, \\
& & 106 \\
& Aviation Uses & $2,12,15,18,19,25,41,44,62,63,64$, \\
& & $65,66,67,68,69,70,71,78,79,80,85$, \\
\end{tabular}

\section{1. Civil Uses}

Virtual reality as noted above has many uses in today's society and just in the past twenty years has made vast improvements. The first cases of virtual reality came to surface in the early 1950s, when a cinematographer named Morton H. Eilig created a system of fans, speakers, and displays to a moving chair called the Sensorama [33]. This gave the user a more surreal environment to watch television. Later on in the 1960s, Philco designed the first Helmet Mounted Display (HMD), which was called the Headsight. The helmet had a screen attached to it that was attached to a camera system to give the user a sight outside of the helmet. The Headsight was the basis for what helicopter pilots used to fly in the dark and assist their vision while flying. As technology progressed more and more scientist like Ivan Sutherland developed additional HMD tethered to computers to give the user a more immersed experience.

Since these early developments, virtual reality and their systems have improved and expanded to more fields other than just entertainment. Medical professionals use virtual reality to perform and practice on common and uncommon procedures. Engineers use virtual reality to design and create structures without having to waste precious time and resources. Students and employees use virtual reality for training and learning by creating an environment that cannot be created in a traditional classroom setting. Telecommunication is a field that is just starting to evolve into a more effective facilitator of human interaction. Being able to speak with someone or see someone on the other side of the world but feel like they are right beside you is what researchers strive for. Some people want to bring their favorite sport home with them or inside when weather is not always the best. Sports like golf have been brought inside to where the average person can play without having to step foot outside. In business, products can be designed and tested without having to fully produce the product. This can be exceptionally helpful to see if a product has harmful side effects on the world or population. Going to space can be real expensive, and demanding on a lot of people for a short trip. Space is an experience only few have felt and since scientist cannot constantly send people to space to prepare them for what they will see, scientist have to bring the feeling of space to the astronaut. Many machines and simulators can give an astronaut a close feeling to being in space without harming them or spending so much money. Finally the largest area virtual reality fills is entertainment. Entertainment technology today is more advanced. The average person can leave reality and experience many things they could only dream of. From flying a jet, playing instruments and sports, to even being on a vacation without leaving to go on a trip.

Healthcare in the world has become more and more technologically advanced in the last few years than it ever has before. With the aid of technology, medical professionals are constantly learning more and preparing to take care of patients every day. In school, students can learn to diagnose patients by using human simulators without the need of having a sick person in front of them. These methods can be used to test Emergency Medical Technicians (EMT) on how they respond to accidents and scenes, where in this case a few seconds or minutes could be someone's life. Babies are born every day. With the aid of technology, nursing schools have adopted simulators that can recreate the birthing process and teach people what to expect without having to be in a room putting more stress on the mother or harming the baby. Virtual reality can help doctors practice operating procedures on a computer without having a human serving as their first subject, which reduces the doctors' stress by not having a person's life in their hands. Post-Traumatic Stress Disorder (PTSD) and other patients dealing with mental disorders or illnesses can use virtual reality as 
therapy to help patients reach a more healthy state. Virtual reality is a large help in the medical field for everyone, but it is not a direct replacement for cadavers and testing, yet it can be a great tool for everyone from the patient to the doctor.

In the engineering world, technology and virtual reality are used in every step of the design process. From the first idea and concept all the way through the construction phase and testing phase. Using programs like Computer-aided design (CAD) and other 3D generating programs, engineers can create their ideas and concepts on a screen much faster than building mock versions or smaller scales of the design. In the computer, the engineers can look for faults in the design or flaws in the product's aesthetic look. Once completed, it can then be tested on the computer using software like AutoCAD. AutoCAD can bring the object to life and make it function like it would in real life. Engineers can make it break, test its limits, find common faults and go back to the design process to fix them. Once satisfied the product can be built for further testing and finally sent to the public as a final product. Engineers use virtual reality in construction and buildings, the automobile industry, aviation, technology, and pretty much on most of the products we use today. The same concept can be applied to art and crafting. More and more people are designing logos, fashion, and art on a computer screen or tablet as opposed to paper and pencil. When designed on a computer, common mishaps of the elements or art getting damaged on transport can easily be avoided. Once finished, their final piece can be ported and sent out with a few clicks of a button and seen by many people across the world.

Education systems across the world vary depending on where the student studies. Computers have been incorporated in more public and private schools for younger ages to increase their available methods of learning. Virtual reality in the classrooms bring even more interactive learning for children and young adults with tools like digital white boards connected to the computer as a display and a write on board. In colleges, students with technological based degrees spend most of their classes on a computer connected to other computers for lectures. Projects and assignments are all completed and turned in through technology. Businesses are incorporating the same ideas and processes into training their employees to work in their facilities. Computer based training for safety, processes, and to keep the employee up-to-date on the company is a common practice. It helps the employee retain more knowledge as opposed to the standard instructor lecturing to students in a plain classroom.

In the world, sports is used as a large form of entertainment, fitness, and to just pass the time with friends or family. Virtual reality has advanced by incorporating sports into the technological world. For instance, golf can be played inside on a projector with an electronic club. The player can project a display on a wall and play golf whenever they feel like it. When Nintendo released its console the Nintendo Wii, their largest game seller was Wii Sports. The user can play multiple sports like tennis, baseball, golf, and bowling in the comfort of their own home. The Wii also released a game called Wii Fit, where the user could exercise and get in shape like they were in a gym.

In science fiction books and movies, talking to someone else via a holographic image or through a monitor or screen was always a thought of the future. In today's society this is partially possible with the use of applications like Skype and FaceTime by Apple, where two people can talk to each other through a camera and screen. To improve our ability to communicate with others in other parts of the globe, scientists are continuing to research methods that incorporate virtual reality into telecommunications. For example, a group of students from Osaka University in Japan created a machine that two users can use to teleconference each other and to shake a robotic hand [20]. When they shake the hand, it replicates the texture, strength, and warmth of the other user's hand. It makes them feel as if they both were there. This makes it possible for people on other sides of the world able to meet and discuss business or just have a casual greeting with each other.

With all these advancements in virtual reality, we have made large leaps in entertainment and fun activities. As with the advances in sports, giving people feelings and experiences they may never have or possibly could have is the goal for some scientist. As noted above, simulators for the public allow people to fly jets or other aircraft, ride roller coasters without being there, and even venture the world. For example, with 3D movies and IMAX films viewers feel like they are in the movie and a part of the film. Through these technologies, documentaries can make people feel like they are in whatever area they are watching, as if they are following the film crew. In the early 1990s, Nintendo created the Virtual Boy system, which was a set of goggles on a stand the user looked into and played games on. Unfortunately, the system was badly reviewed and was not easy to play. Even though it was not considered a good game system, it led to the research and development of new virtual reality games. 


\subsection{Civil Aviation Uses}

Virtual Reality or virtual maintenance systems are computer-generated environments that can be interacted with and are used for training purposes or inspections. Virtual Reality is used in many different fields such as medical, military, research purposes, and the aviation industry. The Air Force is a branch of the military where virtual reality has been used greatly to help train pilots quickly and efficiently. Virtual reality is widely used by military and commercial airlines for aircraft inspection to ensure that everything is working properly and to make sure the aircraft is safe for flight. Virtual reality is used to train pilots in a realistic environment so they can experience different flight conditions, but within a safe environment [36]. Virtual reality simulation allows military personnel to experience dangerous situations and learn how to adapt to different scenarios, but without the risk of death or injury [36]. The Aviation Industry requires mandatory training throughout the career of everyone involved. Commercial airlines and the military have both been using virtual simulations for more than seventy years to train new pilots [36]. In order to keep up with the most recent methods and guidelines, training is a must. Virtual training has come a long way and continues to be an essential part in bringing much success to the aviation industry.

There are several different uses of virtual reality in the aviation industry. The most noted use for virtual reality is training pilots and aircraft inspections. Aircraft inspections and maintenance are an essential part of safe and reliable transportation. Training has been identified as the primary intervention strategy in improving inspection performance. Aircraft maintenance is a factor that should be at the top of the list and the training for aircraft maintenance is never-ending. Virtual aircraft maintenance training has made it much easier for the trainees to grasp a strong hold of the concepts of aircraft maintenance. Visual inspection skills can be taught effectively using representative photographic images showing a wide range of conditions with immediate feedback on the trainee's decision in a controlled environment. Inspection is regulated by the Federal Aviation Administration (FAA), as is maintenance. There are organizations out there that solely develop virtual trainers to help ensure safety.

Aerosim Technologies has developed virtual maintenance trainers for several different aircrafts. An example of one aircraft type is the Boeing 737 NG. The Virtual Maintenance Trainer ${ }^{\mathrm{TM}}$ is a simulation-based training device designed to optimize training time and improve the learning process for maintenance personnel. The Virtual Flight Deck (VFD) and the Virtual Aircraft (VA) are combined for training on component location, system logic/operation, troubleshooting, fault isolation procedures, and return-to-service tests. The Virtual Flight Deck (VFD) is a full simulation of your aircraft's specific flight deck brought to life on a PC. With the VFD, maintenance technician trainees can scan, view and operate all panels, controls, indicators and displays within the flight deck. Virtual Aircraft (VA) enables technicians to perform external component location, walk around inspection and procedure based interaction. Users are able to perform practical exercises to include operational tests (systems and BITE), AMM \& TSM/FIM tasks, MMEL maintenance procedures, and servicing. Active System Schematics are detailed diagrams of the aircraft systems. They show in real-time what is happening within the aircraft systems based on flight deck inputs. These Active System Schematics are tied directly into the simulation in progress. With the advancement of the aviation industry and all the abilities that the aircrafts are now able to perform, maintenance is one of the most important aspects in the industry.

Once maintenance and inspections are performed on the aircraft, the next important aspect in the aviation industry is ensuring that all pilots are properly trained to handle the aircraft and different flight conditions they may face. Pilots have to meet special FAA requirements to obtain a commercial pilot certification. In order to obtain a commercial pilot certification in the US, there are several basic requirements. Once the basic requirements are met, future pilots will go through several areas of testing (FAA.Org). Simulation-based learning has been widely used in the aviation industry for many years (vrs.gov). Aircraft simulators or flight simulators try to replicate the experience of flying an aircraft. Simulators can be simple computer games or the exact replica of a cockpit on hydraulic actuators with highly advanced technology. Simulators are used by the Army, Navy, Air Force, and commercial airlines to train pilots. Flight simulators help pilots develop new skills in handling the aircraft under unusual conditions. There are many difference types of simulators that are widely used in the aviation industry. CAE is a global leader in providing comprehensive training solutions based on world-leading simulation technology and integrated training services. They are the industry's first FAA-approved web-based Virtual Ground School for business aircraft pilot recurrent training. They offer e-Learning with more than 5,000 hours of online courses, including general operating subjects, basic aviation studies, aircraft type-specific, and maintenance training courses. CAE e-Learning programs are available anywhere anytime. There are many companies like CAE that help the everyday pilot keep up-to-date with the latest training methods online that greatly reduces costs.

Air Force pilots go through rigorous training installments to be the best of the best at what they do. A key factor in the training for Air Force pilots is that of flight simulators. Pilots in the Air Force today are 
now able to rely on virtual reality training methods to improve their skills. The Air Force uses virtual reality as part of their training systems. The most well-known use are flight simulators which are designed to teach flying skills but within a safe environment. Simulators are used to train military pilots for combat missions and aim to allow the pilots to feel a sense of immersion and to feel as if they are flying a real aircraft, but without the dangers of flying a real aircraft in a combat zone. Simulators are programmed to mimic the movements of a real aircraft and provide feedback to the pilot. Reality Media is a private company that specializes in the design, development, and production of state-of-the-art simulators, as well as training systems [100]. Virtual Reality Media's Mi-171 full flight / full mission simulator provides all the equipment and software support necessary for ground and flight operations training [100]. The six degree of freedom (six DoF) motion platform, realistic control loading system (CLS) and vibrating seats create a realistic training experience [100].

Full-flight simulators are the most capable aviation training devices. Full-flight simulators replicate aircraft characteristics with a high level of fidelity and help the pilot trainee experience different conditions they may encounter during flight. Full-Flight simulators have both visual and motion capabilities and are incredibly accurate in allowing the pilot to experience exactly what flying the aircraft would be like. As shown in Figure 1, the flight training devices are different from full flight simulators in that they are not always motion capable, but are sophisticated enough to provide training for pilots.

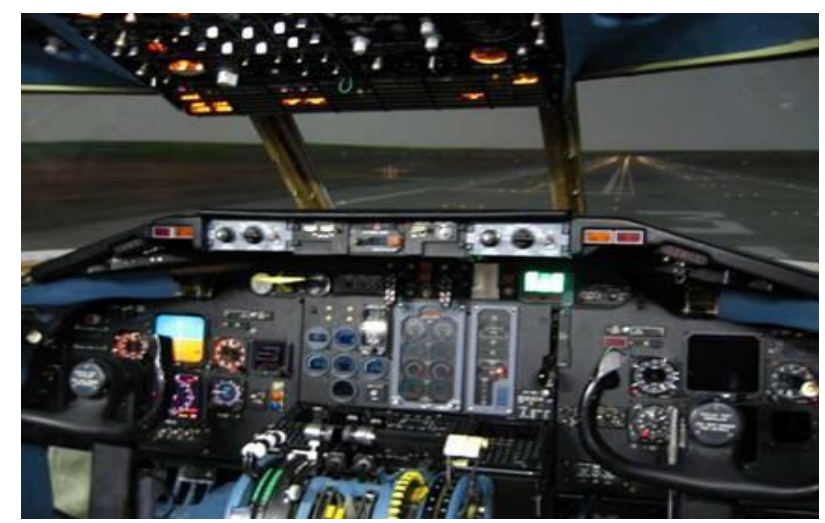

Figure 1. Completed DC-9 Flight Simulator Cockpit

Virtual reality is used to train military pilots to evacuate the aircraft in emergency situations. When forced to evacuate an aircraft mid-flight, it is difficult to think about what course of action should be taken to ensure survival. A device called the Virtual Reality Hanging Harness Trainer is used to give pilots the experience of emergency parachuting out of an aircraft. The simulator allows pilots to experience the feel of a 4000-foot jump while using a computer system to produce different scenarios, such as wind conditions, combat zones, and varying terrains. Parachute instructors will be able to simulate situations where a jump goes wrong, monitor a student's performance, and provide feedback using digital video recordings. "Whilst the trainer will not replace live descents for the trainee parachutists, the opportunity to repeatedly practice drills and react to emergency situations in a safe and, importantly, realistic virtual environment, is invaluable and will greatly enhance training delivery and ultimately safety (http://www.raf.mod.uk/news/archive)."

No matter how skilled a pilot might be, training will always be never-ending. There are always new methods and advanced technology coming out to better assist in safety. Simulators are getting more and more advanced with the never-ending advances in technology. The world of virtual reality has made it much easier for the pilot to train in real-world climates with reduced risk. Virtual reality allows for pilots to remain welltrained and up-to-date on new flight requirements. Most pilots will agree that flight simulation is the quickest, easiest, and most cost efficient route for learning to operate an aircraft. If it were not for virtual training, we would not.

\section{CONCLUSION}

We expect end-to-end virtualization to become a normal part of future training environments. It is noteworthy that providing a virtualization training layer cannot guarantee the effective training for maintenance crew and pilots. The flexibility that makes virtual reality an effective tool should have been 
considered in future development of infrastructures. Current literature related to virtual reality and virtual maintenance has focused largely on the implementation of virtualization and its applications. Therefore, further attention is due to the security risks, required technology for developing infrastructure to meet challenges in virtual maintenance training.

\section{REFERENCES}

[1] Ambani, S., Meerkov, S.M., \& Liang, Z. (2010). Feasibility and optimization of preventive maintenance in exponential machines and serial lines. IIE Transactions, 42(10), 766-777. doi: 10.1080/07408171003749209.

[2] Andre, T.S., Bennett, W.R., Castillo, A.R., McClain, D.P., Purtee, M.D., Wenzel, B.M., and Graci. M. (2003). Generalized operations simulation environment for aircraft maintenance training. RTO HFM Symposium on Advanced Technologies for Military Training, RTO-MPHFM-101, Genoa, Italy, 13-15 October 2003.

[3] ARMY.MIL, The Official Homepage of the United States Army. (2012, August 1). Retrieved April 3, 2015, from http://www.army.mil/article/84453/.

[4] Badler, N.I., Erignac, C.A., \& Liu, Y. (2002). Virtual humans for validating maintenance procedure. Communications of the ACM, 45(7), 56-63.

[5] Baker, M. Pauline. (2014). Virtual reality. In AccessScience. McGraw-Hill Education. Retrieved from http://0www.accessscience.com.athens.iii.com/content/virtual-reality/757461.

[6] Barot, C. Lourdeaux, D., Burkhardt, J. Amokrane, K. Lenne, D. (2013). V3S: A Virtual Environment for RiskManagement Training based on Human-Activities Model. Presence-Teleoperators and Virtual Environments. 22(1): 1-19.

[7] Baumann, J (1993). Military applications of Virtual Reality. Retrieved from Hiti.Washington.edu on April 20, 2016.

[8] Beaty, J. (2006). Handbook of virtual environments. Organizational Research Methods, 9(1), 113-118.

[9] Bell, H.H., The Effectiveness of Distributed Mission Training. Communications of the ACM, 42(9), 72-78.

[10] Briggs, J.C. (1996). The promise of virtual reality. The Futurist, 30(5), 13. Retrieved from http://search.proquest.com.athens.iii.com/docview/218591583?accountid=8411

[11] Briggs, J. C. (2002). Virtual reality is getting real: Prepare to meet your clone. The Futurist, 36(3), 34-46.

[12] Boeing's I/ITSEC 2009 Technology Demonstrations. (2009). Military Technology, 33(12), 76.

[13] Bouchard, S., Baus, O., Bernier, F., \& McCreary, D.R. (2010). Selection of Key Stressors to Develop Virtual Environments for Practicing Stress Management Skills with Military Personnel Prior to Deployment. Cyberpsychology, Behavior \& Social Networking, 13(1), 83-94.

[14] Boughouas, H., Boukebbab, S., Bouchenitfa, H., \& Amara, I. (2008). Control by virtual gauge of skew surfaces for correction process. International Journal of Advanced Manufacturing Technology, 36(9/10), 936-941.

[15] Bowling, S.R., Khasawneh, M.T., Kaewkuekool, S., Xiaochun, J., \& Gramopadhye, A.K. (2008). Evaluating the Effects of Virtual Training in an Aircraft Maintenance Task. International Journal of Aviation Psychology, 18(1), 104-116.

[16] Butavicius, M.A., Vozzo, A., Braithwaite, H., \& Galanis, G. (2012). Evaluation of a Virtual Reality Parachute Training Simulator: Assessing Learning in an Off-Course Augmented Feedback Training Schedule. International Journal of Aviation Psychology, 22(3), 282-298.

[17] Bymer, L. (2012). Virtual Reality used to train soldiers in new training simulator. Retrieved from www.army.mil.2012 on April 28, 2016.

[18] CAE E-Learning. (n.d.). Retrieved from http://www.cae.com/civil-aviation/business-aviation/cae-e-learning/ on April 28, 2016.

[19] CAE Virtual Ground School. (n.d.). Retrieved from http://www.cae.com/civil-aviation/business-aviation/trainingcourses/cae-virtual-ground-school/ on April 28, 2016.

[20] Crane, P. (1999). Implementing distributed mission training. Communications of the ACM, 42(9), 90-94.

[21] Cressey, D. (2011). Q\&A: The virtual trainer. Nature, 477(7365), 406=408.

[22] Danigelis, A. (n.d.). Robotic Hand Shakes Yours for Long Distance Greeting: DNews. Retrieved, from http://news.discovery.com/tech/robotics/robotic-hand-shakes-yours-for-long-distance-greeting-140428.htm on April 5, 2015

[23] Deitz, D. (1995). Real engineering in a virtual world. Mechanical Engineering, 117(7), 78. Retrieved from http://search.proquest.com.athens.iii.com/docview/230159906?accountid=8411 on April 28, 2016.

[24] Emily, A.T., \& Bodary, M. (2000). Virtual reality, combat, and communication. Journal of Business and Technical Communication, 14(3), 315-327.

[25] FAA (2014). FAA lab using virtual reality to improve aviation safety. Retrieved, from http://www.pressofatlanticcity.com/communities/eht/faa-lab-using-virtual-reality-to-improve-aviationsafety/article_3e030a56-ef5c-11e3-a2a0-001a4bcf887a.html on April 2, 2015

[26] Feldmann, K., \& Christoph, F. (2003). Virtual prototyping of placement machines in electronics production. International Journal of Computer Integrated Manufacturing, 16(7/8), 479-485.

[27] Gaoliang, P., Yu, H., Liu, X., Jiang, Y., \& Xu, H. (2010). A desktop virtual reality-based integrated system for complex product maintainability design and verification. Assembly Automation, 30(4), 333-344.

[28] Garfinkle, T., Rosenblum, M. (2005). Which Virtual is harder than Real; Security challenges in Virtual Machine based computing environments. Proceedings of the 10th Workshop. 2005. Retrieved from https://www.usenix.org/legacy/event/hotos05/final_papers/full_papers/garfinkel/garfinkel.pdf on April 28, 2016. 
[29] Gopher, D. (2012). Skill training in Multimodal virtual environments. Work, 412284-2287. Retrieved from http://0-web.b.ebscohost.com.athens.iii.com/ehost/detail/detail?vid=22\&sid=f7b990fa-eef3-46be-8edc8a593db0bf16\%40sessionmgr114\&hid=109\&bdata=JnNpdGU9ZWhvc3QtbGl2ZQ\%3d\%3d\#db=buh\&AN=7192 8607 April 28, 2016.

[30] Gorman PJ, Meier AH, \& Krummel TM. Simulation and Virtual Reality in Surgical Education: Real or Unreal? Arch Surg. 1999; 134(11): 1203-1208.

[31] Goolsby, C., Vest, R., \& Goodwin, T. (2014). New Wide Area Virtual Environment (WAVE) Medical Education. Military Medicine, 179(1), 38-41.

[32] Gwebu, K.L., Wang, J., \& Troutt, M.D. (2007). A conceptual framework for understanding trust building and maintenance in virtual organization. JITTA: Journal of Information Technology Theory and Application, 9(1), 4363.

[33] Hassouneh, D., \& Brengman, M. (2011). Virtual worlds: A gateway for SMEs toward internationalization. Journal of Brand Management, 19(1), 72-90.

[34] Hays, R.T., Vincenzi, D.A. (2002). Fleet Assessments of a Virtual Reality Training System. Military Psychology (Taylor and Francis Ltd), 12(3), 161-186.

[35] Henderson, L. (2013). Clinical Technologies. Applied Clinical Trials, 22(12), 18-22.

[36] History of Virtual Reality. (n.d.). Retrieved April 5, 2015, from http://www.vrs.org.uk/virtual-reality/history.html

[37] Howard, C.E. (2012). Immersive training for an agile, adaptable force. Military and Aerospace Electronics, 23(11), 10-17.

[38] Hubal, R. (2005). Design and usability of military maintenance skills simulation training systems. Proceedings of the Human Factors and Ergonomics Society Annual Meeting (pp. 2110-2114). Santa Monica, CA: Human Factors and Ergonomics Society.

[39] Huegal, J. Celik, O., Israr, A., O’Malley, M., Expertise-Based Performance Measures in a Virtual Training Environment. Presence: Teleoperators and Virtual Environments, 18(6), 449-467.

[40] Jameston, H., Interactive and Immersive Training. Military Technology. 2011. 35(5). 56-63.

[41] Jean, G.B. (2009). Unmanned Aerial Vehicles Join the Virtual Fight. National Defense, 93(668), 32-33.

[42] Jenab, K., \& Zolfaghari, S. (2008). A virtual collaborative maintenance architecture for manufacturing enterprises. Journal of Intelligent Manufacturing, 19(6), 763-771.

[43] Ji, P., Choi, A.C.K., \& Tu, L. (2002). VDAS: A virtual design and assembly system in a virtual reality environment. Assembly Automation, 22(4), 337-342.

[44] Jian, C., \& Xiumin, F. (2010). Dynamic Model of an Astronaut Equipped with a Manned Maneuvering Unit in Virtual Reality. Journal of Aerospace Engineering, 23(2), 139-145.

[45] Kaber, D. 13, Riley, J.M., Endsley, M.B., Sheik-Nainar, Zhang, T., Lampton. D.R., (2013). Measuring Situation Awareness in Virtual based Training. Military Psychology (American Psychology Association), 25(4), 330-344.

[46] Kao, Y., Tsai, J., Cheng, H., \& Chao, C. (2011). Development of a virtual reality wire electrical discharge machining system for operation training. International Journal of Advanced Manufacturing Technology, 54(5-8), 605-618.

[47] Lam, C.K., Sundaraj, K., \& Sulaiman, M.N. (2013). A Review of Computer-Generated Simulation in the Pedagogy of Cataract Surgery Training and Assessment. International Journal of Human-Computer Interaction, 29(10), 661-669.

[48] Landers. R.N., Callan. R.C. (2012). Training Evaluation in Virtual Worlds: Development of a model. Journal of Virtual Worlds Research. 5(3). 1-22.

[49] Larsen, C.R. Oestergaard, J., Ottesen, B.S. \& Soerensen, J.L. (2012). The efficacy of virtual reality simulation training in laparoscopy: a systematic review of randomized trials. Acta Obstetricia Et Gynecologica Scandinavica, 91(9), 1015-1028. doi: 10.1111/j.1600-0412.2012.01482.x

[50] Lateef, F (n.d.). Simulation-based learning: just like the real thing. Journal of Emergencies, Trauma, and Shock, 3(4), 348-352.

[51] Li, D., Huang, W., Chen, C., \& Chang, C. (2013). Employing virtual samples to build early high-dimensional manufacturing models. International Journal of Production Research, 51(11), 3206-3224. doi: 10.1080/00207543.2012.746795

[52] Li, X., Gao, Q., Zhang, Z., \& Huang, X. (2012). Collaborative virtual maintenance training system of complex equipment based on immersive virtual reality environment. Assembly Automation, 32(1), 72-85. doi: http://0dx.doi.org.athens.iii.com/10.1108/01445151211198737

[53] Liu, X., Cui, X., Song, G., \& Xu, B. (2014). Development of a virtual maintenance system with virtual hand. International Journal Of Advanced Manufacturing Technology, 70(9-12), 2241-2247. doi: 10.1007/s00170-0135473-0

[54] Liu, X., Peng, G., Liu, X., \& Hou, Y. (2012). Disassembly sequence planning approach for product virtual maintenance based on improved max-min ant system. International Journal of Advanced Manufacturing Technology, 59(5-8), 829-839. doi: 10.1007/s00170-011-3531-z

[55] Lövquist, E., Shorten, G., \& Aboulafia, A. (2012). Virtual reality-based medical training and assessment: The multidisciplinary relationship between clinicians, educators and developers. Medical Teacher, 34(1), 59-64. doi: 10.3109/0142159X.2011.600359.

[56] Luecke, G.R. (2012). GREENSPACE: Virtual Reality Interface for Combine Operator Training. Presence: Teleoperators \& Virtual Environments, 21(3), 245-253. 
[57] Meyer, G.F., Li Ting, W., Timson, E., Perfect, P., White, M.D., \& Ernst, M.O. (2012). Objective Fidelity Evaluation in Multisensory Virtual Environments: Auditory Cue Fidelity in Flight Simulation. Plos ONE, 7(9), 114. doi: 10.1371/journal.pone.0044381.

[58] Military applications of virtual reality. (n.d.). Retrieved April 2, 2015, from http://www.hitl.washington.edu/projects/knowledge_base/virtual-worlds/EVE/II.G.Military.html

[59] Moore, P.R., Ng, A.C., Yeo, S.H., Sundberg, M., Wong, C.B., \& De Vin, L.J. (2008). Advanced machine service support using Internet-enabled three-dimensional-based virtual engineering. International Journal of Production Research, 46(15), 4215-4235. doi: 10.1080/00207540600969790.

[60] Moskalivk, J. Betram, J., Cress, V., Impact of Virtual Training Environments on the Acquisitions and Trasnfer of Knowledge. CyberPsychology, Behavior and Social Networking. 16(3). 210-214. 2013.

[61] Mueller, D., \& Strohmeier, S. (2010). Design characteristics of virtual learning environments: an expert study. International Journal of Training \& Development, 14(3), 209-222. doi: 10.1111/j.1468-2419.2010.00353.x.

[62] Nambisan, S., \& Baron, R.A. (2009). Virtual Customer Environments: Testing a Model of Voluntary Participation in Value Co-creation Activities. Journal of Product Innovation Management, 26(4), 388-406. doi: 10.1111/j.1540-5885.2009.00667.x.

[63] Nakayama, S., \& Jin, G. (2015). Safety training: Enhancing outcomes through virtual environments. Professional Safety, 60(2), 34-38.

[64] Niu, L., \& Yuan, Y. (2011). A parallel decomposition algorithm for training multiclass kernel-based vector machines. Optimization Methods \& Software, 26(3), 431-454. doi: 10.1080/10556788.2011.556633.

[65] Noor, A.K. (2009). Disruption from virtual world. Mechanical Engineering, 131(11), 22-28.

[66] Nugent, W.R. (1991). Virtual reality: Advanced imaging special effects let you roam in cyberspace. Journal of the American Society for Information Science (1986-1998), 42(8), 609-918.

[67] Ong, S.K., Yuan, M.L., \& Nee, A.C. (2008). Augmented reality applications in manufacturing: a survey. International Journal of Production Research, 46(10), 2707-2742. doi: 10.1080/00207540601064773.

[68] Parsons, D. (2012). Soldiers Test Impact of Virtual Training on Live-fire Performance. National Defense, 97(709), 34-36.

[69] Patel, H., \& Cardinali, R. (1994). Virtual reality technology in business. Management Decision, 32(7), 5-18.

[70] Piccoli, G., Ahmad, R., \& Ives, B. (2001). Web-Based Virtual Learning Environments: A Research Framekwork and a Preliminary Assessment of Effectiveness in Basic IT Skills Training. MIS Quarterly, 25(4), 401-426

[71] Pop, E., Leba, M., \& Neghina, F. (2009). Software Oriented Adaptive Controller for a Mining Elevator. Revista Minelor / Mining Revue, 15(6), 2-8.

[72] PRACTICED HANDS. (2006). PC Magazine, 25(17), 20.

[73] Ohab, J. (2010). Three ways virtual reality can improve military training. Retrieved on May 15, 2016, from http://science.dodlive.mil/2010/07/30/three-ways-virtual-reality-can-improve-military-training/.

[74] Qiu S, Fan X, Wu D, He Q, \& Zhou D. (2013). Virtual human modeling for interactive assembly and disassembly operation in virtual reality environment. International Journal of Advanced Manufacturing Technology. 69(9-12), $2355-2372$.

[75] Rigelsford, J. (2004). Virtual reality technology. Assembly Automation, 24(1), 127-129.

[76] Rooks, B. (1999). The reality of virtual reality. Assembly Automation, 19(3), 203-212

[77] Rose, F.D, Altree, E.A., Brooks, B.M., Parslow, D.M., Penn, P.R. (2000). Training in virtual environments; transfer to real world tasks and equivalence to real task training. Ergonomics. 43(4), 494-511.

[78] Rosenberg, B. (2002). Lockheed Martin Demonstrates Virtual Maintenance Software. Aviation Week and Space Technology. 156(14), P. 89.

[79] Ruffaldi, E., Filippeschi, A., Avizzano, C.A., Bardy, B., Gopher, D., \& Bergamasco, M. (2011). Feedback, Affordances, and Accelerators for Training Sports in Virtual Environments. Presence: Teleoperators \& Virtual Environments, 20(1), 33-46.

[80] Sanders, P. (2010), Boeing 787 Training takes a Virtual Path. The Wall Street Journal.

[81] Scales, B. (2013). Virtual Immersion Training: Bloodless Battles for Small Unit Readiness. Army Magazine, 63(7), 24-27.

[82] Seo, J., \& Kim, G.J. (2002). Design for Presence: A Structured Approach to Virtual Reality System Design. Presence: Teleoperators \& Virtual Environments, 11(4), 378-403. doi: 10.1162/105474602760204291.

[83] Seymour, N.E., Gallagher, A.G., \& Satava, R.M. (2002). Virtual Reality Training Improves operating Room Performance. Annals of Surgery. 236(4), 458-464.

[84] Shchurov, I. (2011). Calculation of the virtual pitch thread diameter using the cloud of points from CMM. International Journal of Advanced Manufacturing Technology, 53(1-4), 241-245. doi: 10.1007/s00170-010-2815$\mathrm{z}$.

[85] Shey-Huei, S., Chin-Chih, C., \& Yen-Luan, C. (2010). A Generalized Periodic Preventive Maintenance Model With Virtual Age for a System Subjected to Shocks. Communications In Statistics: Theory \& Methods, 39(13), 2379-2393. doi: 10.1080/03610921003778142.

[86] Spiteri, A.V., Aggarwal, R., Kersey, T.L., Sira, M., Benjamin, L., Darzi, A.W., \& Bloom, P.A. (2014). Development of a virtual reality training curriculum for phacoemulsification surgery. Eye, 28(1), 78-84. doi: 10.1038/eye.2013.211

[87] Sumitani, D., Egi, H., Tokunaga, M., Hattori, M., Yoshimitsu, M., Kawahara, T., \& Ohdan, H. (2013). Virtual reality training followed by box training improves the laparoscopic skills of novice surgeons. Minimally Invasive Therapy \& Allied Technologies, 22(3), 150-156. doi: 10.3109/13645706.2012.721377. 
[88] Summers, J.E., Simulation-Based Military Training: An Engineering Approach to Better Addressing Competing Environmental, Fiscal, and Security Concerns. Journal of the Washington Academy of Sciences, 98 (1), 9-30.

[89] Sun, S., \& Tsai, L. (2012). Development of virtual training platform of injection molding machine based on VR technology. International Journal of Advanced Manufacturing Technology, 63(5-8), 609-620. doi: 10.1007/s00170-012-3938-1.

[90] Sun, Y., \& Zhang, W. (2009). Studying energy-oriented dynamic optimization in Java virtual machines. Journal of Circuits, Systems \& Computers, 18(1), 103-120.

[91] Thilmany, J. (2001). Auto center to build virtual reality display. Mechanical Engineering, 123(10), 26-38.

[92] Thorne, K. (2005). Designing virtual organizations? Themes and trends in political and organizational discourses. The Journal of Management Development, 24(7), 580-607.

[93] Tsang, J.S., Naughton, P.A., Leong, S., Hill, A.K., Kelly, C.J., \& Leahy, A.L. (2008). Virtual reality simulation endovascular surgical training. Surgeon (Edinburgh University Press), 6(4), 214-220.

[94] Tworus, R., Szymanska, S., \& Ilnicki, S. (2010). A Soldier Suffering from PTSD, Treated by Controlled Stress Exposition Using Virtual Reality and Behavioral Training. Cyberpsychology, Behavior \& Social Networking, 13(1), 103-107. doi: 10.1089/cyber.2009.0329.

[95] Virtual combat in actual lab. (1997). Civil Engineering, 67(9), 26. Retrieved on May 1, 2016 from http://search.proquest.com.athens.iii.com/docview/228495391 accountid=8411

[96] Virtual Maintenance Trainer Airbus A320. (n.d.). Retrieved May 1, 2016 from from https://www.swiss-aviationtraining.com/en/devices/virtual-maintenance-trainer-airbus-a320

[97] Virtual Reality Training. (1999). USA Today Magazine, 127(2645), 3.

[98] Virtual Reality for aviation training: The IATA Demo. (2015, March 20). Retrieved April 3, 2016, from http://www.brightwave.co.uk/our-thinking/virtual-reality-for-aviation-training-the-iata-demo/index.html

[99] Virtual Reality for soldiers, cops. (1995). The Futurist, 29(6), 44. Retrieved on April 1, 2016 from: http://search.proquest.com.athens.iii.com/docview/218553670?accountid=8411

[100] Virtual Reality Media - Military Aircraft Simulations and Training Systems. (n.d.). Retrieved from http://www.airforce-technology.com/contractors/training/virtual-reality-media/Virtual Reality Prepares Soldiers for Real War. (2006, February 14). Retrieved April 3, 2016, from http://www.washingtonpost.com/wpdyn/content/article/2006/02/13/AR2006021302437.html

[101] Wagner, R.J., \& Campbell, J. (1994). Outdoor-based experiential training: Improving transfer of training using virtual reality. The Journal of Management Development, 13(7), 4-15.

[102] Who We Are. (n.d.). Retrieved from http://www.cae.com/about-cae/corporate-information/who-we-are/

[103] Wittenberg, G. (1995). Training with virtual reality. Assembly Automation, 15(3), 12-18.

[104] Wyche, L.D. (2014). Training and Education Must Leverage Technology and Innovation. Army Sustainment, Retrieved on March 15, 2016 from: http://0-web.b.ebscohost.com.athens.iii.com/ehost/detail/detail?vid= 80\&sid=f7b990fa-eef3-46be-8edc-8a593db0bf16\%40sessionmgr114\&hid=109\&bdata= JnNpdGU9ZWhvc3QtbGl2ZQ\%3d\%3d\#db=f5h\&AN=98622195

[105] Xia, P., Lopes, A.M., \& Restivo, M.T. (2013). A review of virtual reality and haptics for product assembly (part 1): Rigid parts. Assembly Automation, 33(1), 68-77. doi:http://0dx.doi.org.athens.iii.com/10.1108/01445151311294784

[106] Yu, H., Peng, G., \& Liu, W. (2011). A practical method for measuring product maintainability in a virtual $\begin{array}{lllll}\text { environment. Assembly } & \text { Automation, 31(1), 53-61. doi: }\end{array}$ dx.doi.org.athens.iii.com/10.1108/01445151111104173

[107] Yuan, Z., Feng, S., Yin, Q., Wang, X., Zhang, D., Zhao, J., \& Chen, M. (2009). Endoscopic Image Cutting Simulation Based on Mass-Spring Model and Computational Geometry. Journal of Circuits, Systems \& Computers, 18(8), 1453-1465.

[108] Zhou, D., Kang, L., \& Chuan, L. (2013). A virtual reality-based maintenance time measurement methodology for complex products. Assembly Automation, 33(3), 221-230. doi: http://0-dx.doi.org.athens.iii.com/10.1108/AA-122013-048

\section{BIOGRAPHIES OF AUTHORS}

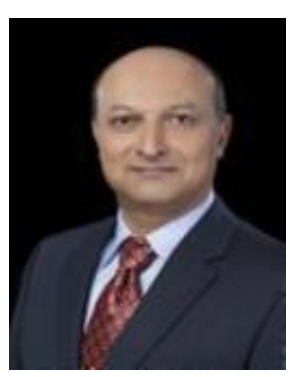

Kouroush Jenab is a senior member of IEEE, received the B.Sc. degree from the IE Department at Isfahan University of Technology (1989), the M.Sc. degree from the IE Department at Tehran Polytechnic (1992), and the Ph.D. degree from the Department of Mechanical Engineering at the University of Ottawa (2005). He served as a senior engineer/manager in auto, and high-tech industries for 18 years. He joined the National Research Council Canada as a research officer where he participated in several international research projects. In 2006, he joined the Department of Mechanical and Industrial Engineering at Ryerson University, Toronto as an assistant professor. Currently, Dr. Jenab is a faculty member of Faculty of College of Business, Athens State University, Athens, AL, USA. He has published over 100 papers in international scientific journals based on his experiences in industries. 

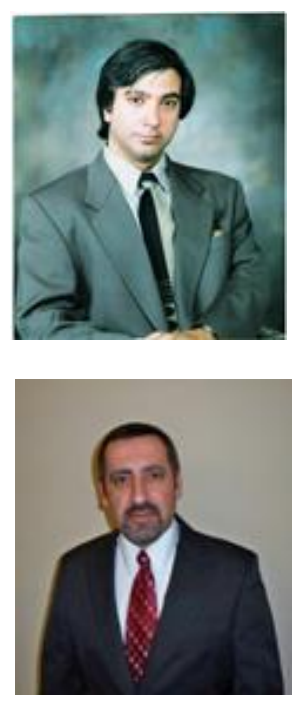

Saeid Moslehpour is a Full Professor in the Electrical and Computer Engineering Department in the College of Engineering, Technology, and Architecture at the University of Hartford. He holds Ph.D. (1993) from Iowa State University and Bachelor of Science (1989) and Master of Science (1990) degrees from University of Central Missouri. His research interests include logic design, CPLDs, FPGAs, Embedded electronic system testing and distance learning.

Sam Khoury is currently the Coordinator of the Computer Information Systems Concentration in the Division of Business at Spring Hill College. He earned his AAS in logistics from the Community College of the Air Force, BAS in business administration from the University of Mount Olive, MSA in general administration from Central Michigan University, and his Ph.D. in organization and management from Capella University. He has over 29 years of experience in information technology and is the former founder and president of SAMIR Systems, Inc., a privately held company specializing in academic software development and support. He has published extensively in the areas of logistics, organization development, information technology, and automation of academic processes. He has also managed the development and implementation of numerous software systems. 